\title{
Detailed Sedimentology and Inorganic Geochemistry of the Dolgeville Formation and Utica Group of the Central Mohawk Valley, NY
}

Daniel Miserendino Jeffrey T. Pietras 


\section{Introduction and Purpose}

- Drill cores present continuous, unweathered rock record ideal for detailed sedimentologic and geochemical studies

- Utica Group (Indian Castle Shale and Flat Creek Shale)

- Trenton Group (Dolgeville Fm.)

- Study the evolution of Ordovician foreland basin by investigating:

- Source terrain

- Seawater chemistry

- Sea level changes

- Depositional processes

- Tectonic processes 


\section{Geologic Setting}

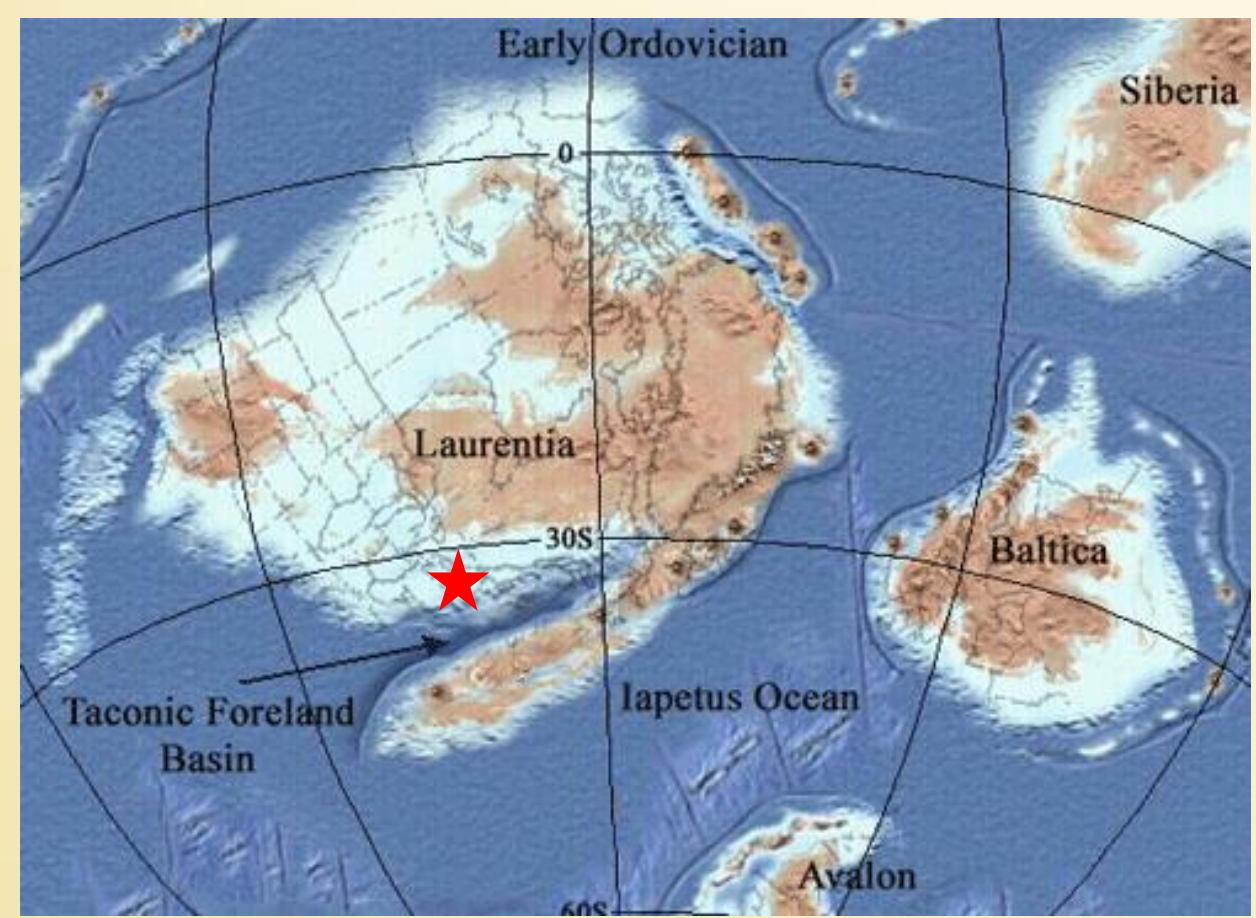

Early Ordovician: Passive margin off southwest Laurentia formed.

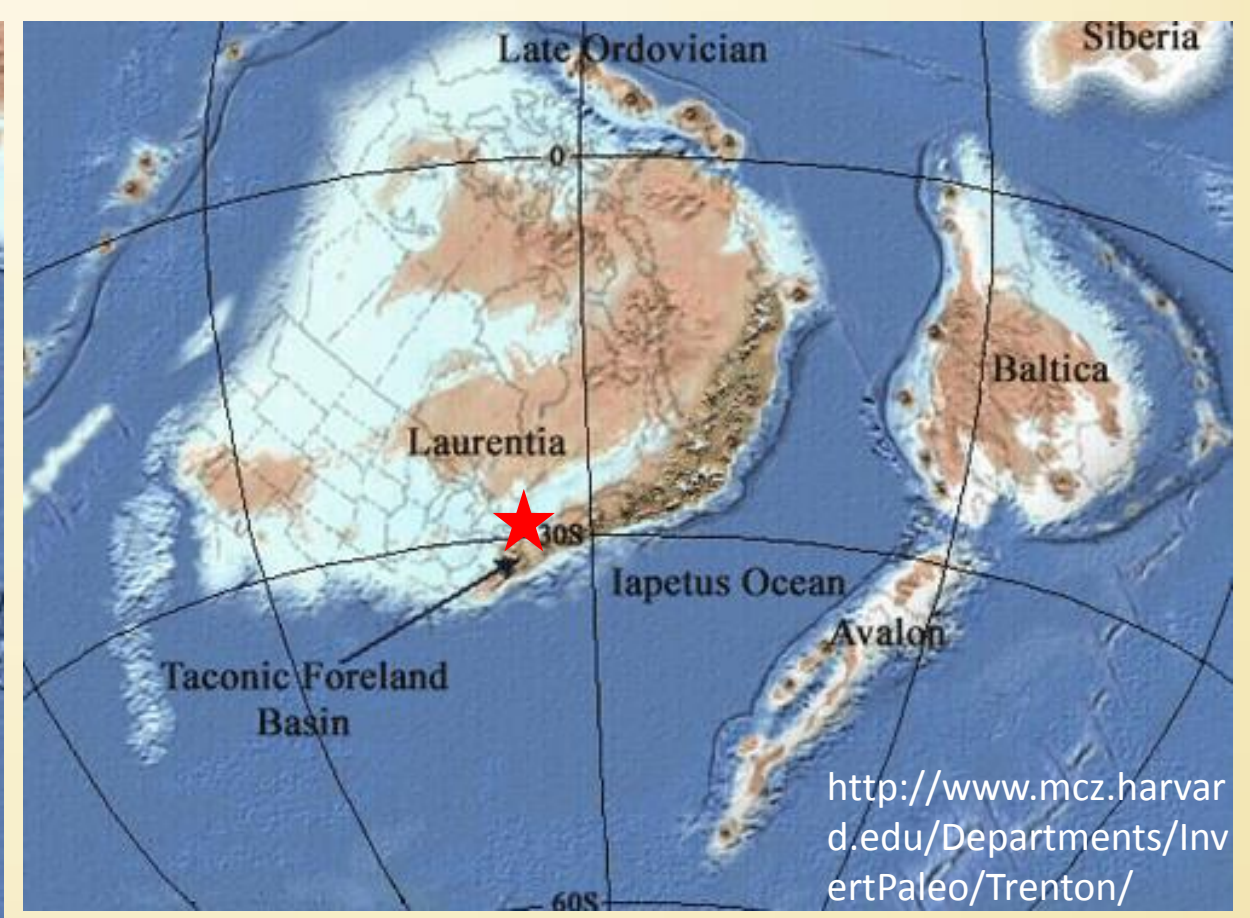

Mid-Late Ordovician: Carbonate platform developed. Onset of Taconic Orogeny. 


\section{Study Area}

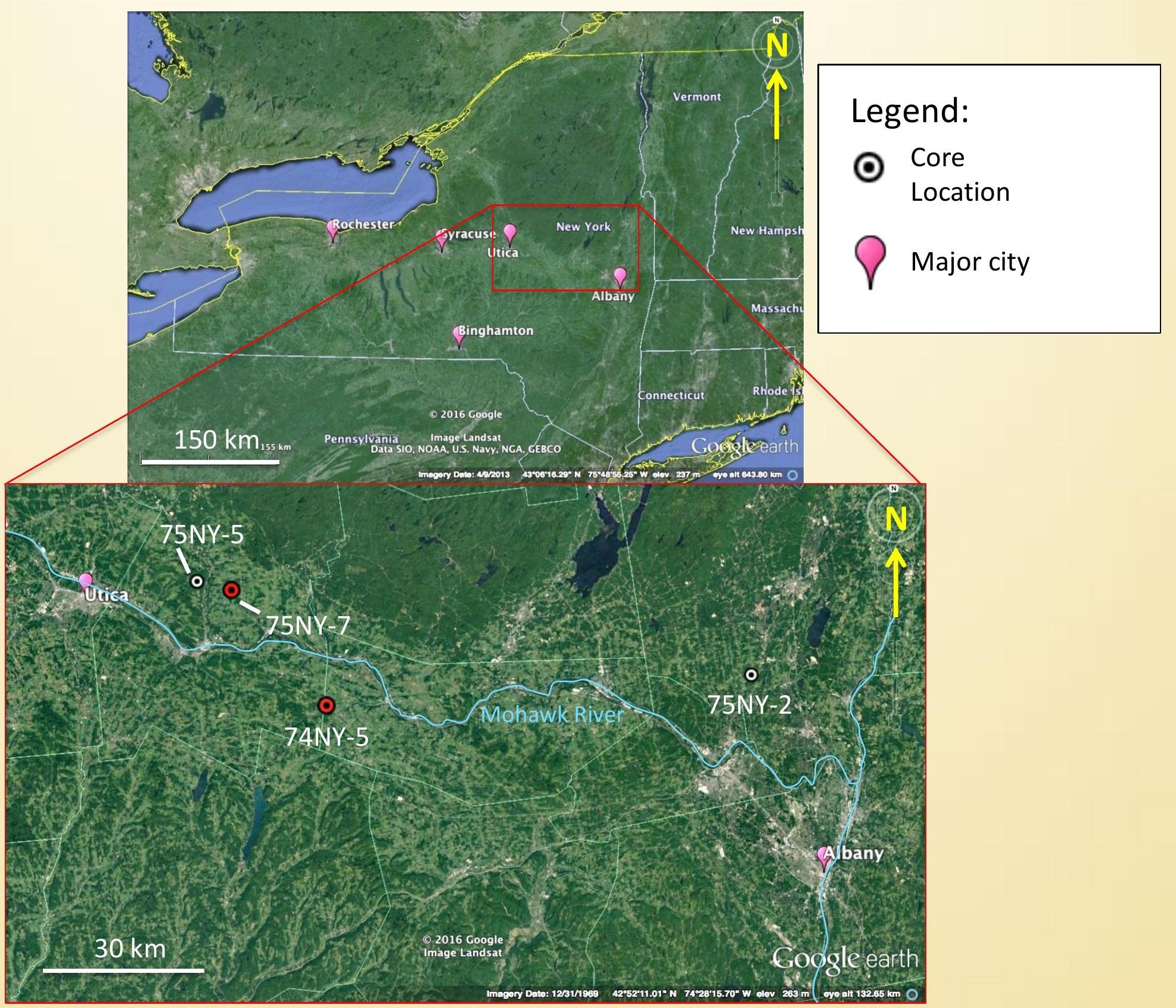




\section{Stratigraphy}

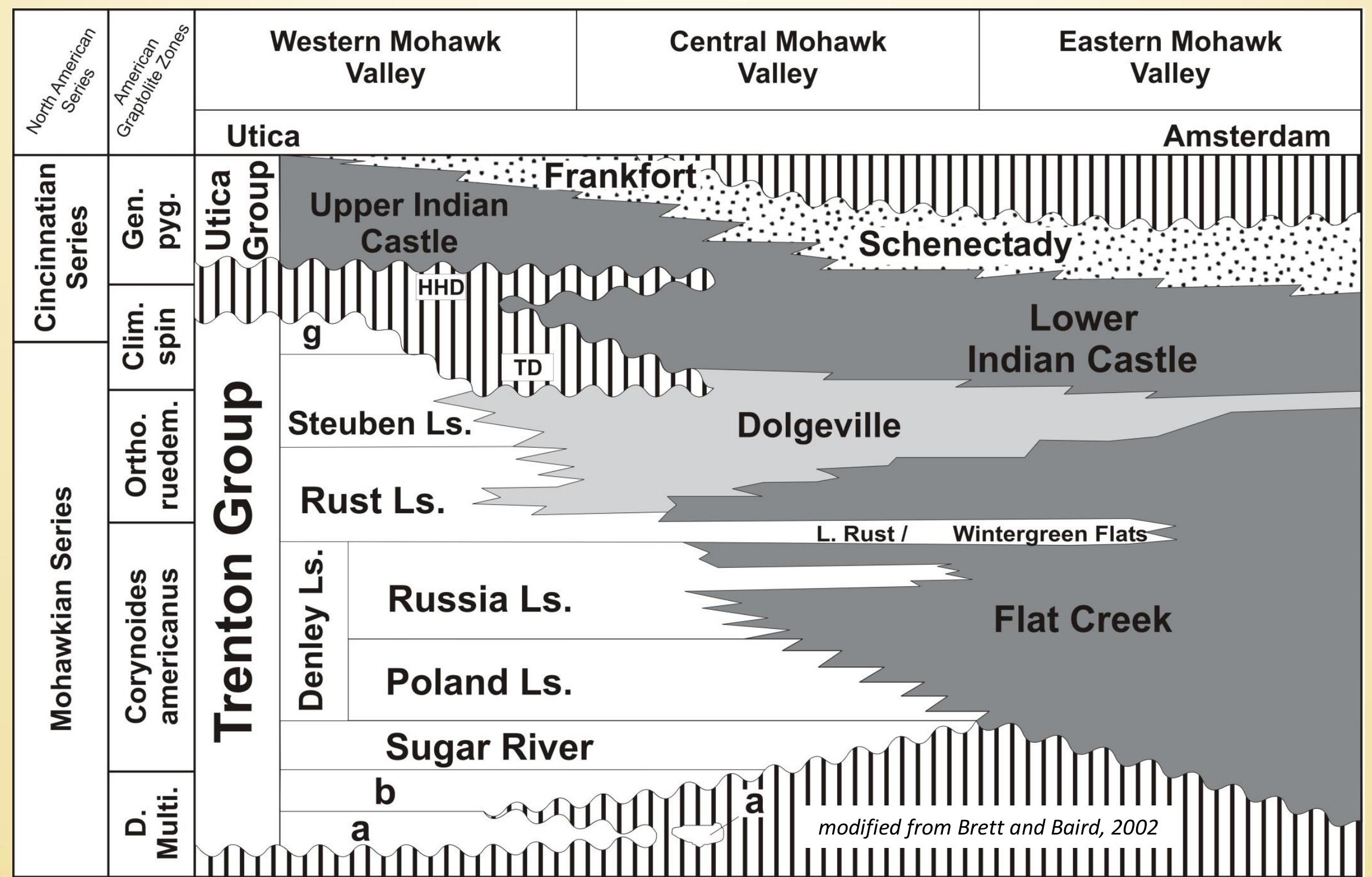




\section{Stratigraphy}

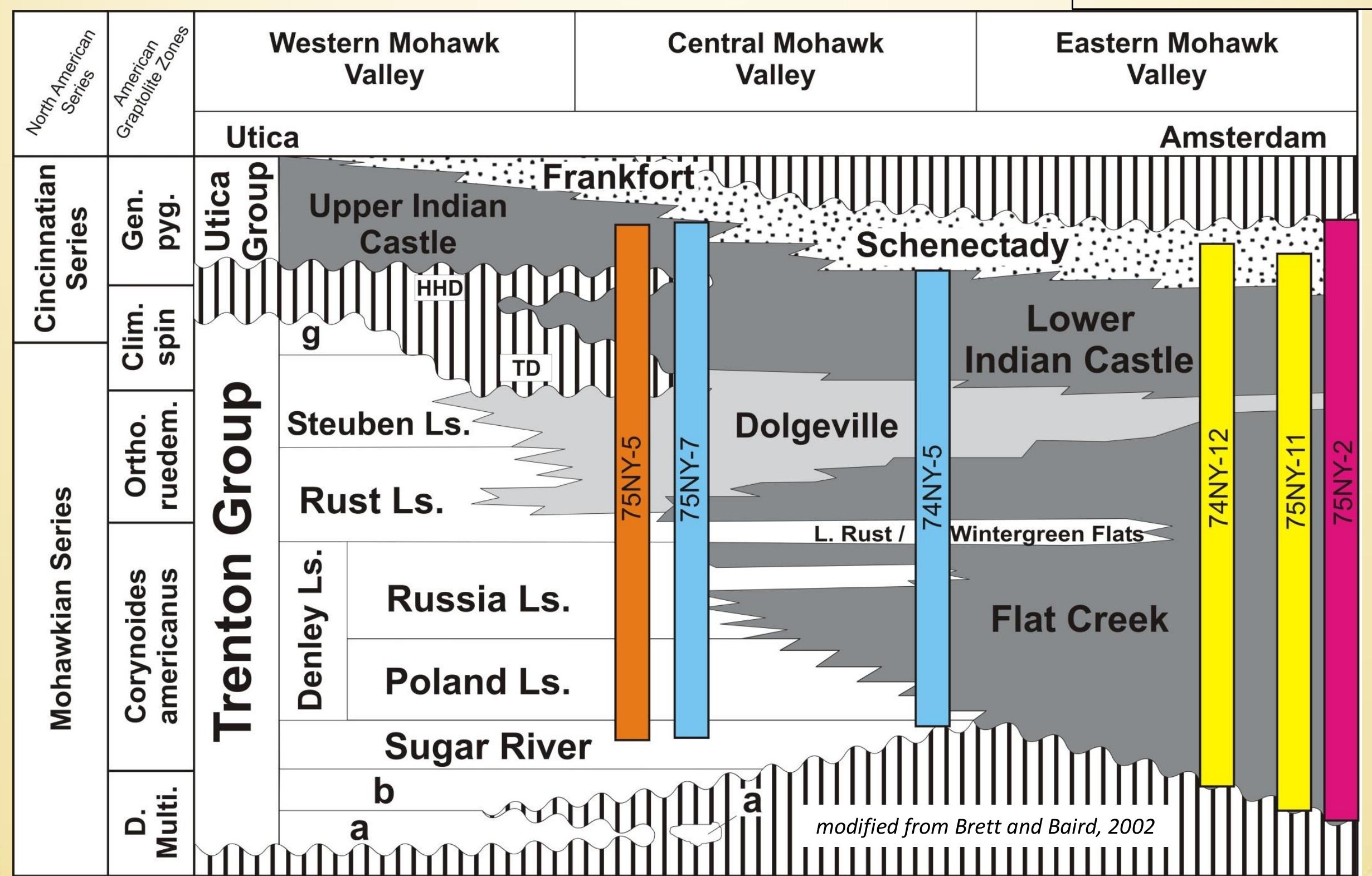


Honey Hill Disconformity

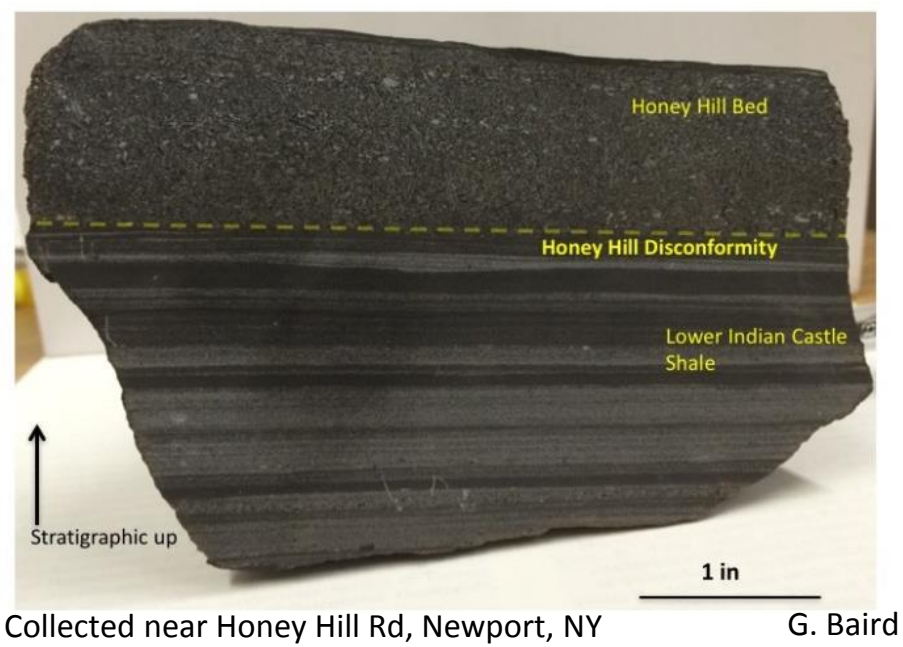

Collected near Honey Hill Rd, Newport, NY

Thruway Disconformity

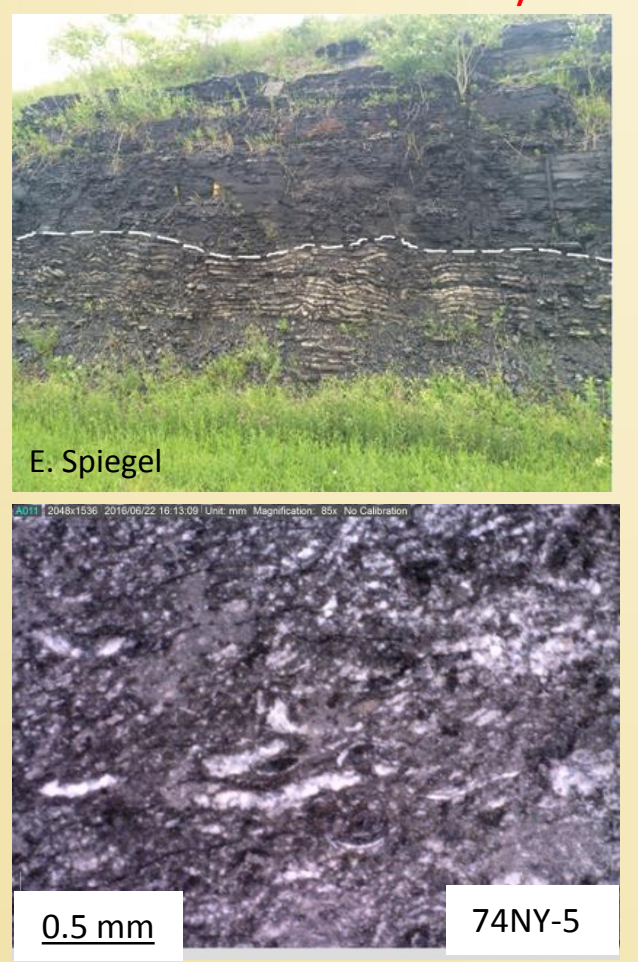

75NY-7

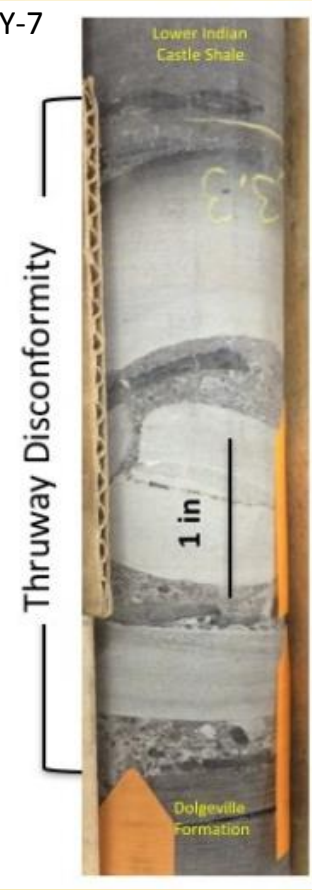

\section{NY-7}

74NY-5

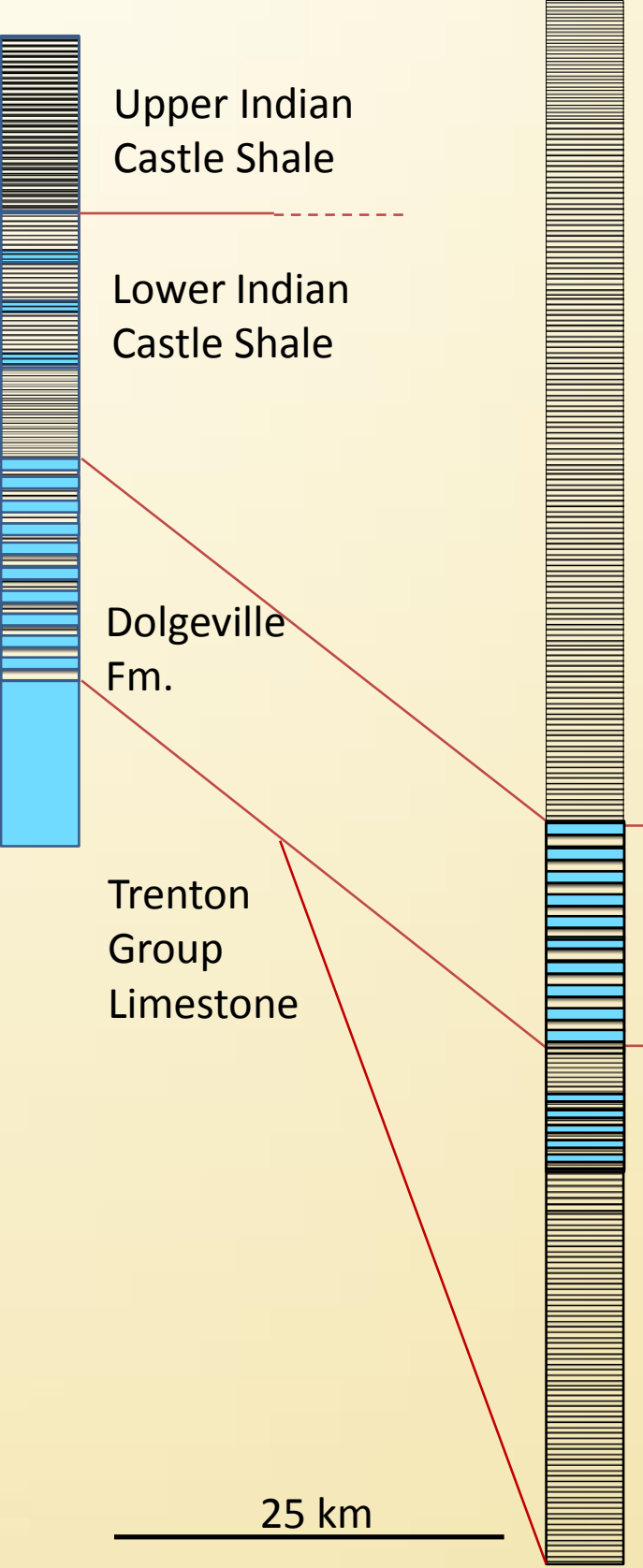

Indian Castle Shale

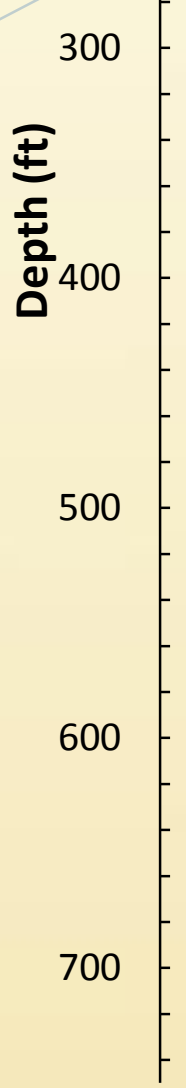

Dolgeville $\mathrm{Fm}$.

Wintergreen Park Interval

Flat Creek Shale 


\section{Dolgeville Formation}

Interbedded limestone and black mudstone

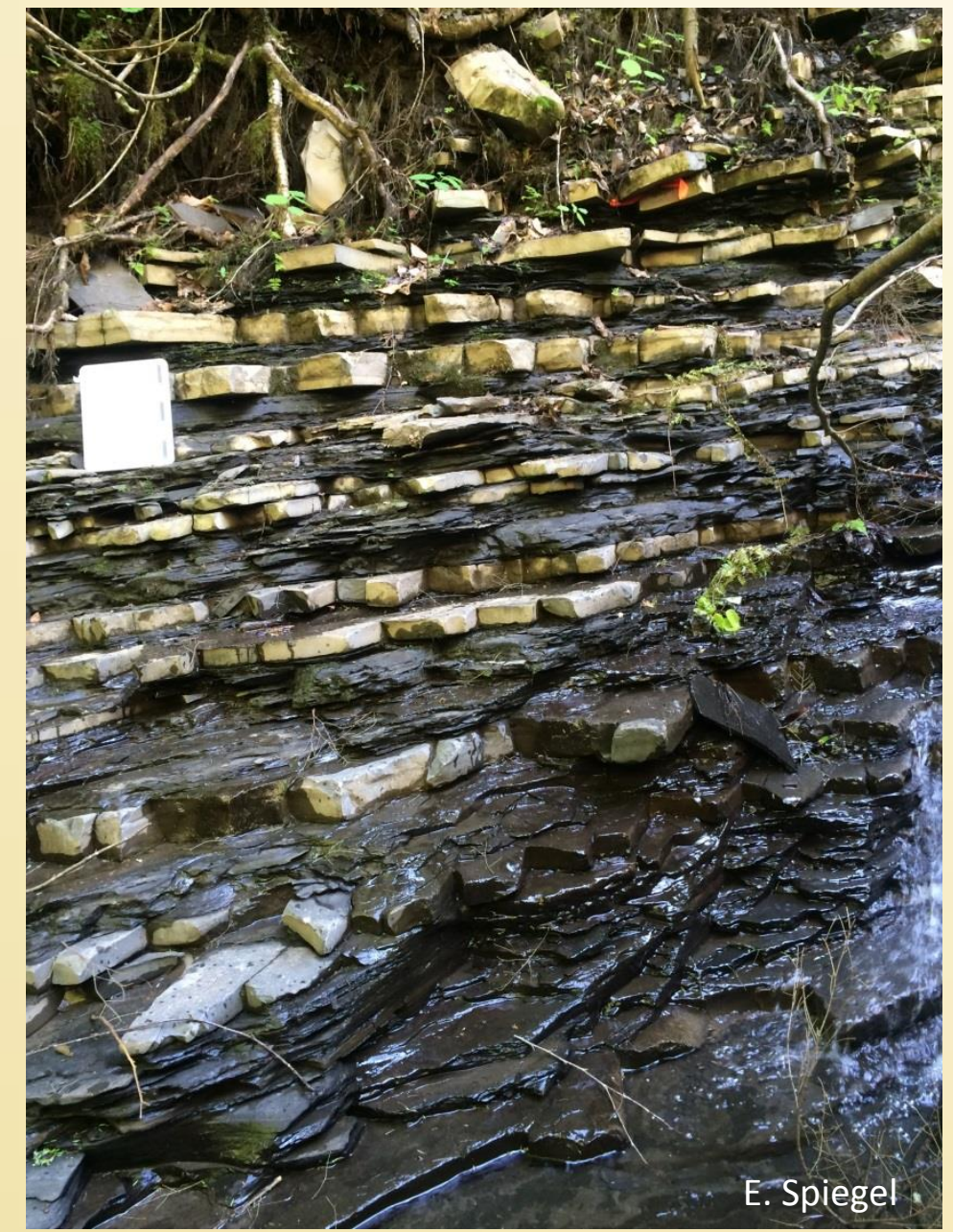

Near County Home, NY

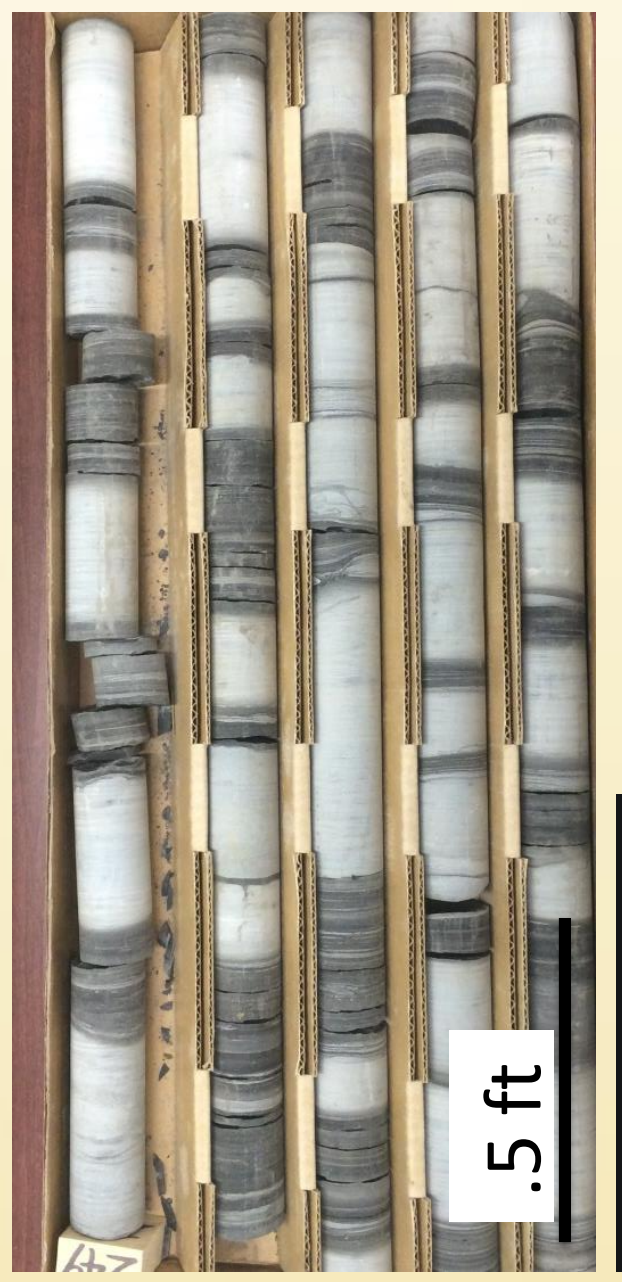

Core 75NY-7
Interpretation:

- Alternating turbidites and low energy, pelagic mud deposition

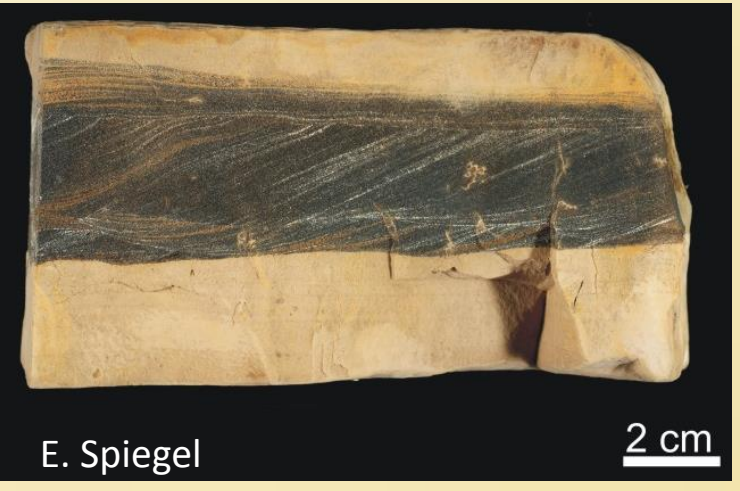




\section{Utica Group}

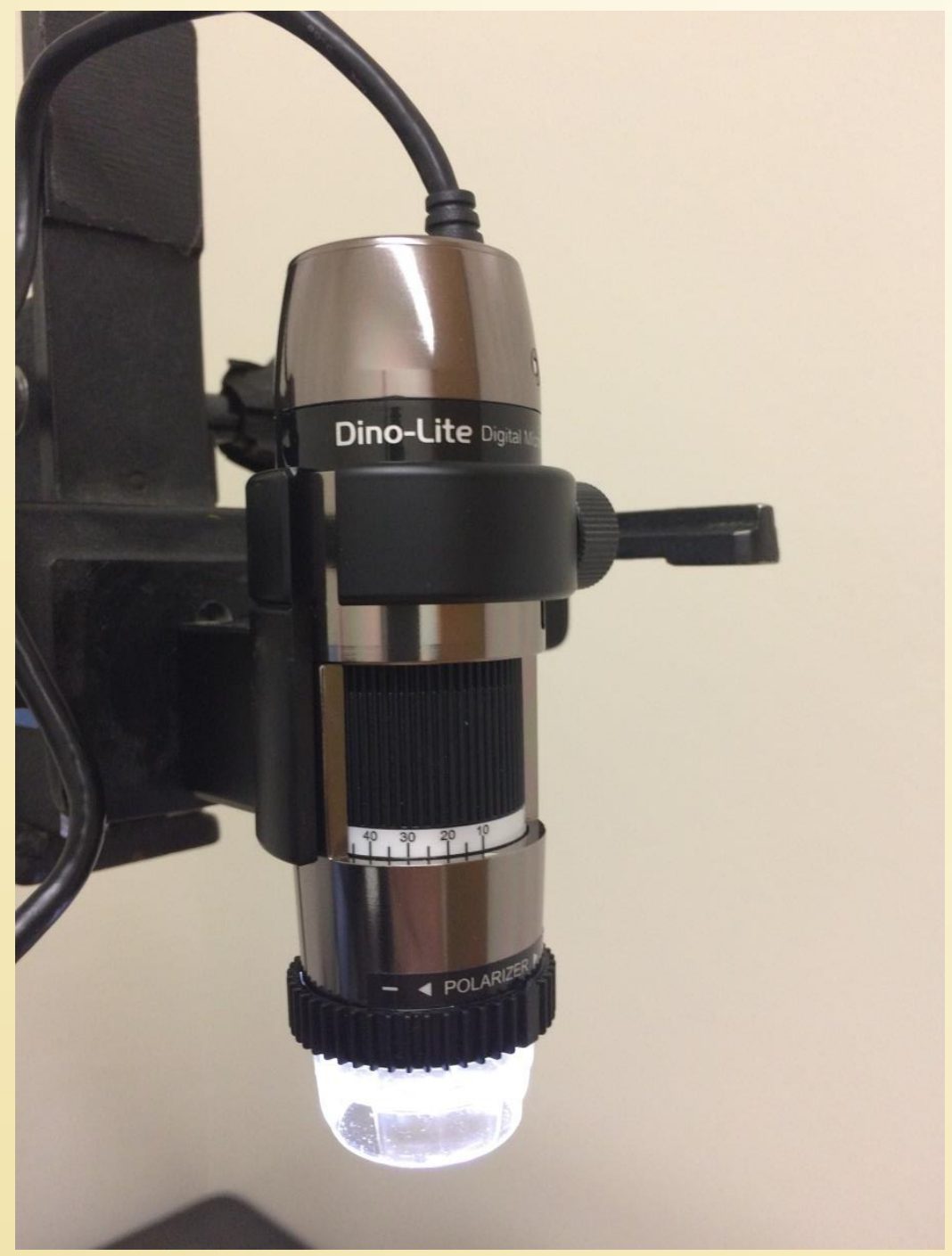

\section{Black mudstone}

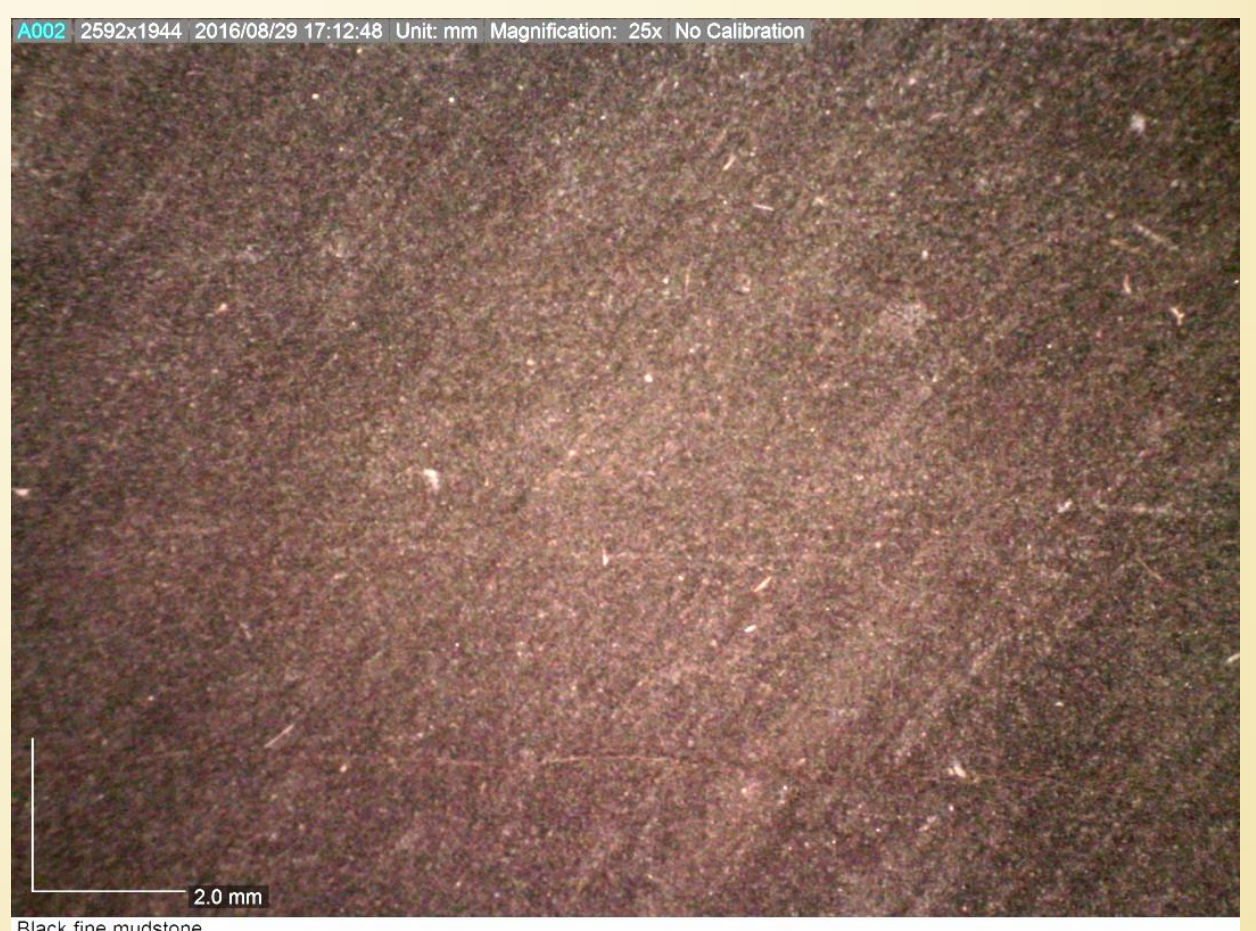

Interpretation:

- Low energy

- Pelagic

- Organic matter accumulation and pyrite

Dino-Lite Edge Digital Microscope 


\section{Banded black mudstone}
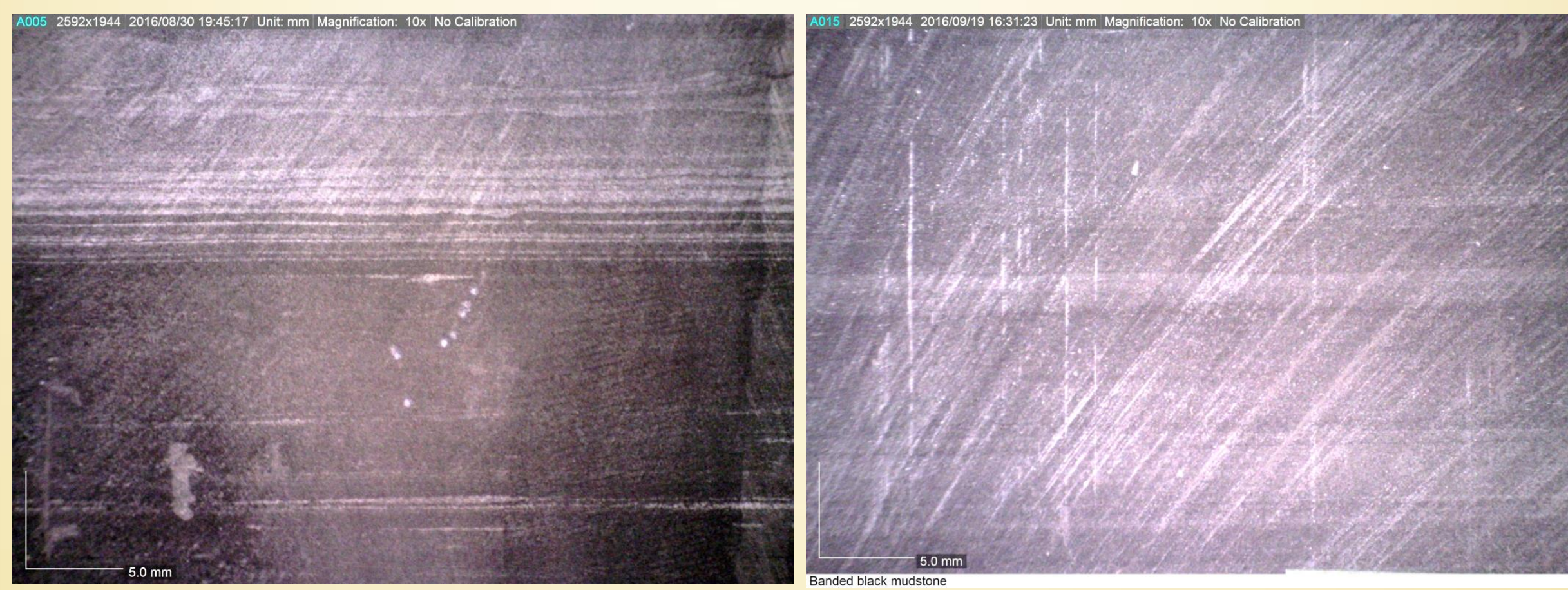

Interpretation:

- Thin turbidites

- Change in pelagic sediment 


\section{Graded gray calcareous silty mudstone}
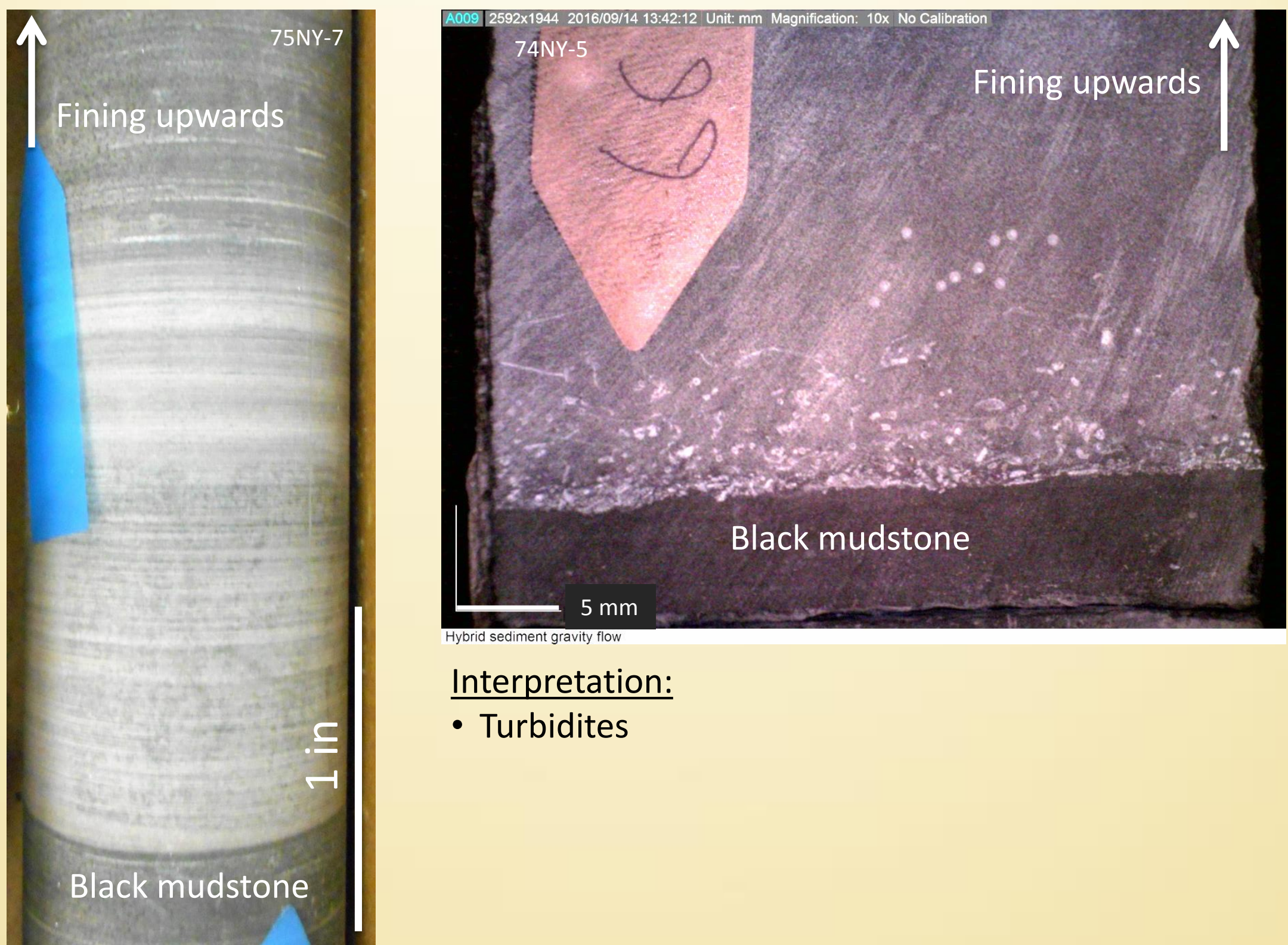

Hybrid sediment gravity flow

Interpretation:

- Turbidites 


\section{Cross-stratified calcareous silty mudstone}

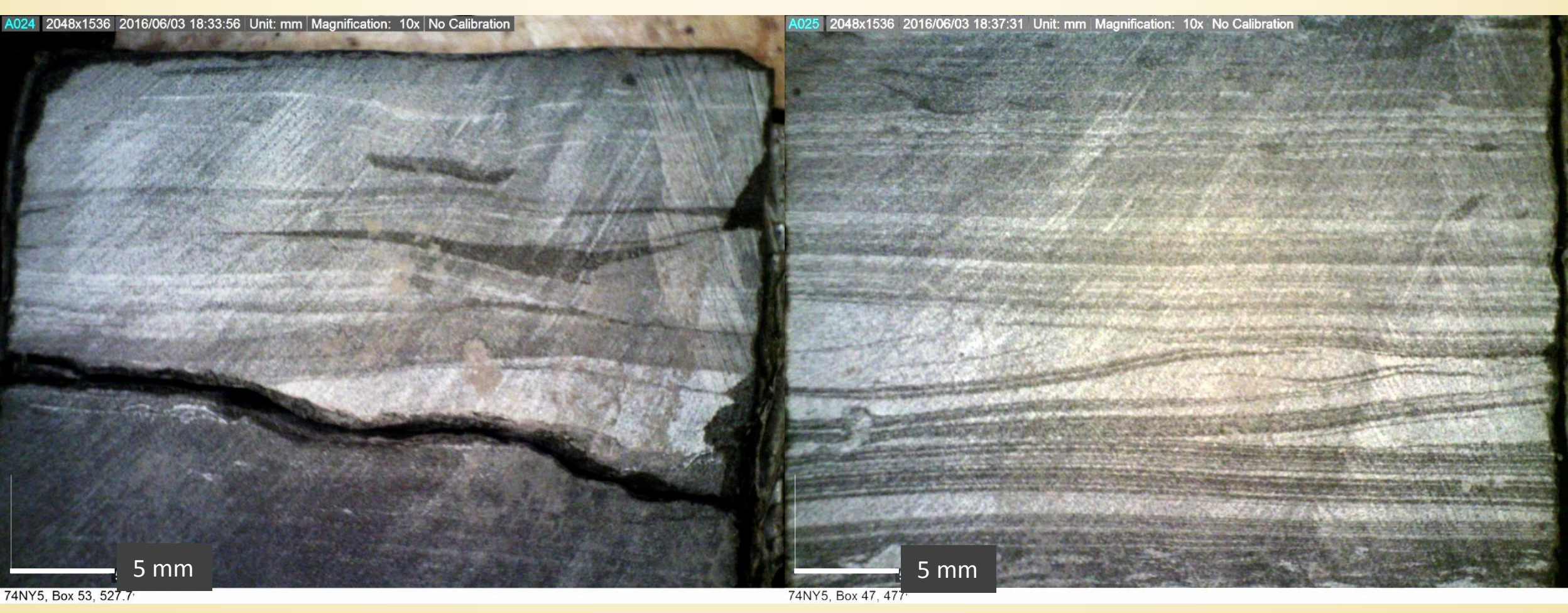

Interpretation:

- Turbidites

- Contourites 


\section{Dark gray silty mudstone}

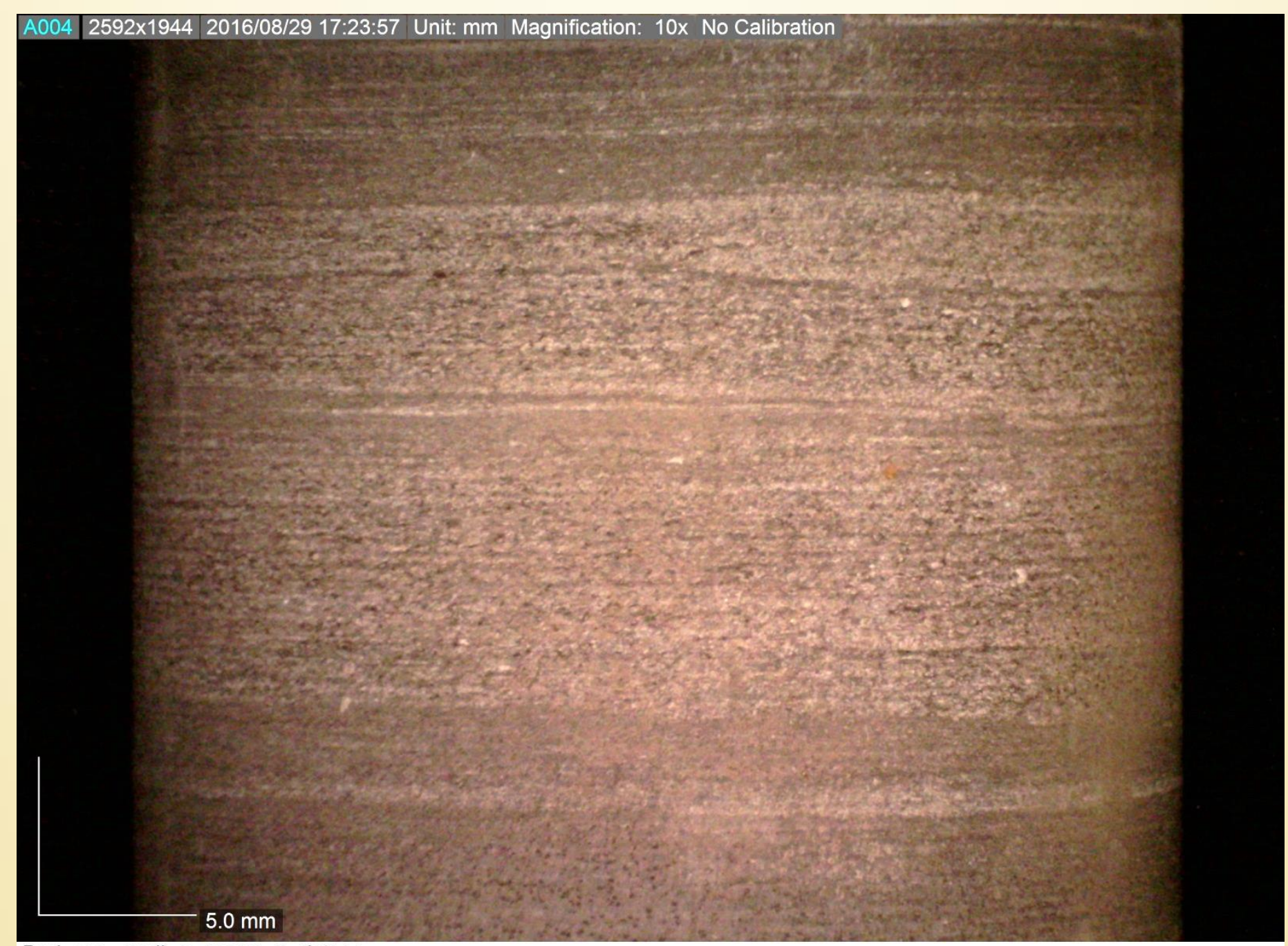

Interpretation:

- Increased silt and sand input

- More siliciclastic input, less carbonates 


\section{Matrix supported sandy mudstone}

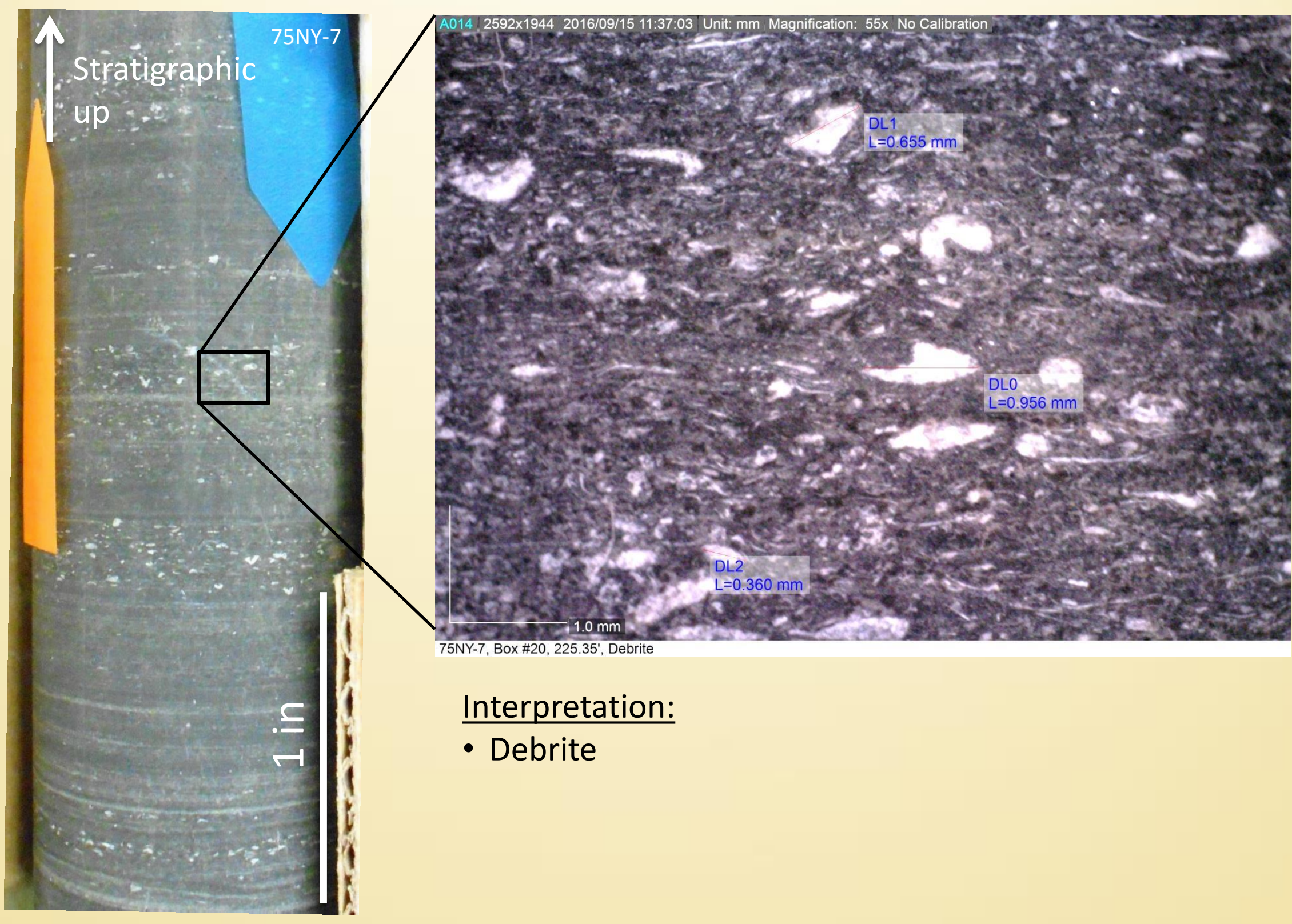




\section{Facies Summary:}

75NY-7

Upper Indian
Castle Shale
- Black mudstone
Lastle Shale




\section{Depositional Summary:}

\section{NY-7}

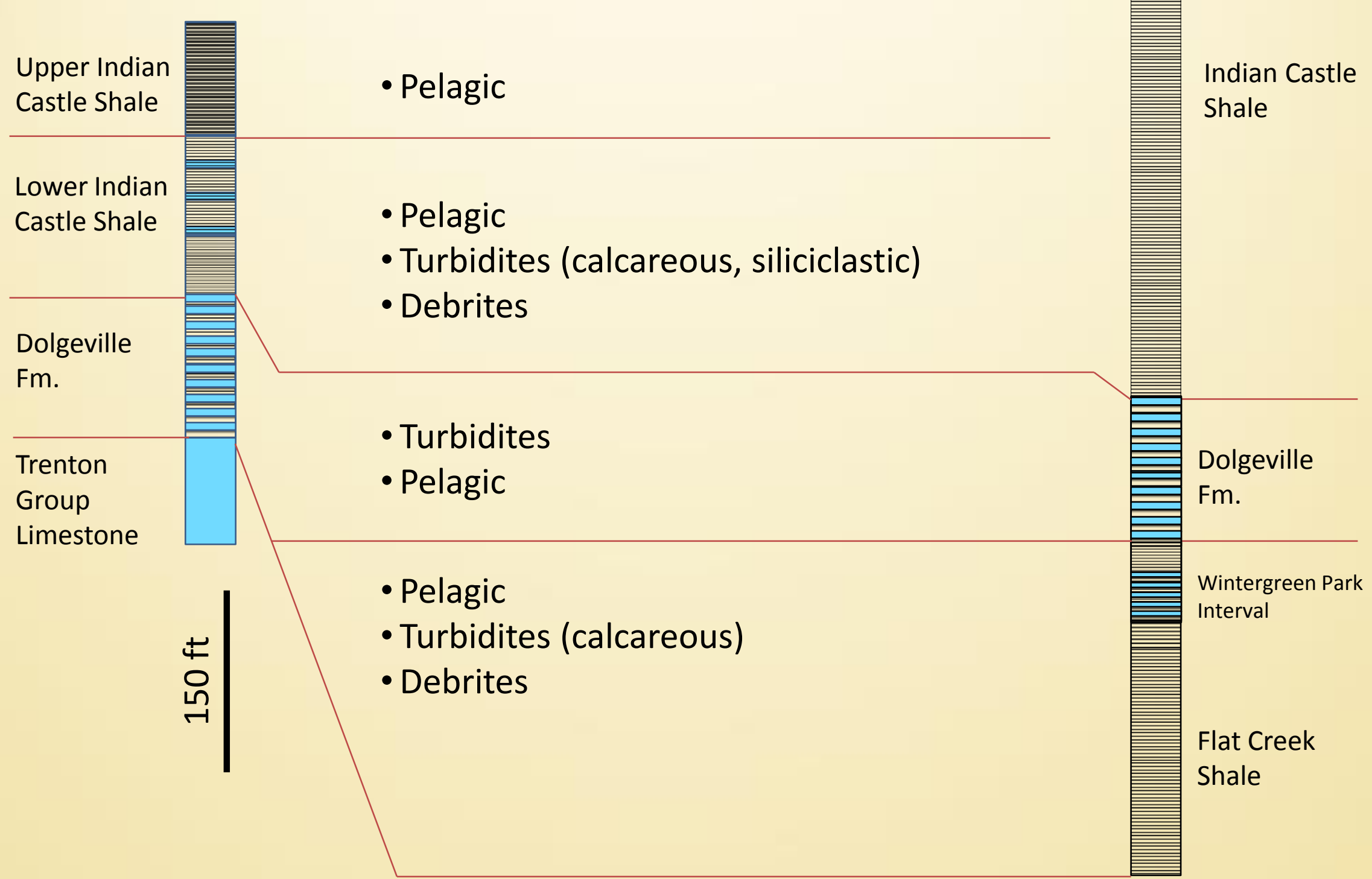




\section{XRF and Rock Hardness}

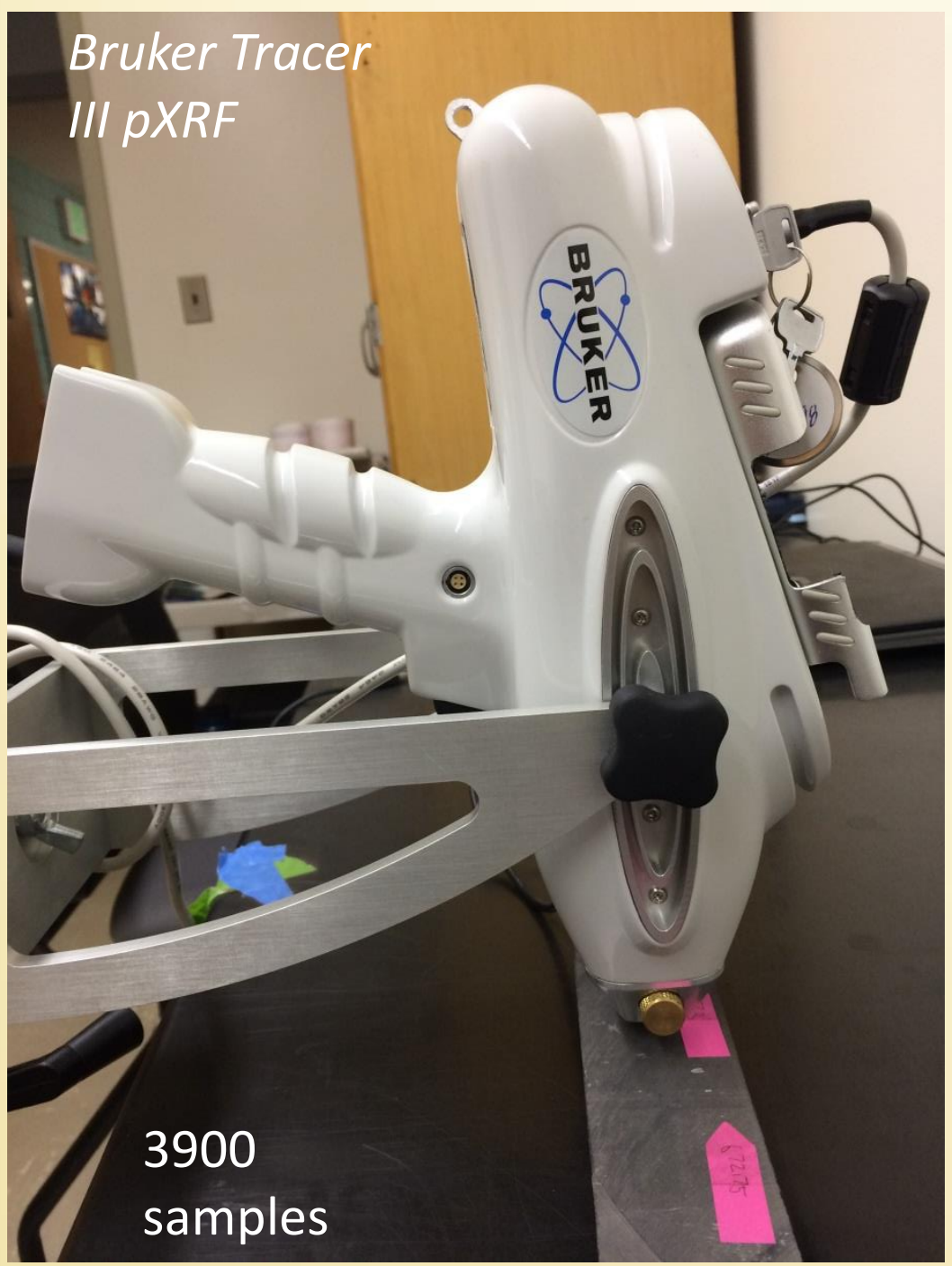

\begin{tabular}{|l|l|l|}
\hline Settings & Mg to $M \mathbf{n}$ & Fe to Mo \\
\hline kV & 15 & 40 \\
\hline$\mu \mathrm{A}$ & 25 & 30 \\
\hline Other & Helium & Yellow Filter \\
\hline
\end{tabular}

Measured elements: $\mathrm{Mg}, \mathrm{Al}, \mathrm{Si}, \mathrm{P}, \mathrm{S}, \mathrm{K}, \mathrm{Ca}, \mathrm{Ba}$, $\mathrm{Ti}, \mathrm{V}, \mathrm{Cr}, \mathrm{Mn}, \mathrm{Fe}, \mathrm{Co}, \mathrm{Ni}, \mathrm{Cu}, \mathrm{Zn}, \mathrm{Ga}, \mathrm{As}, \mathrm{Pb}, \mathrm{Se}$, $\mathrm{Th}, \mathrm{Rb}, \mathrm{U}, \mathrm{Sr}, \mathrm{Y}, \mathrm{Zr}, \mathrm{Nb}, \mathrm{Mo}$

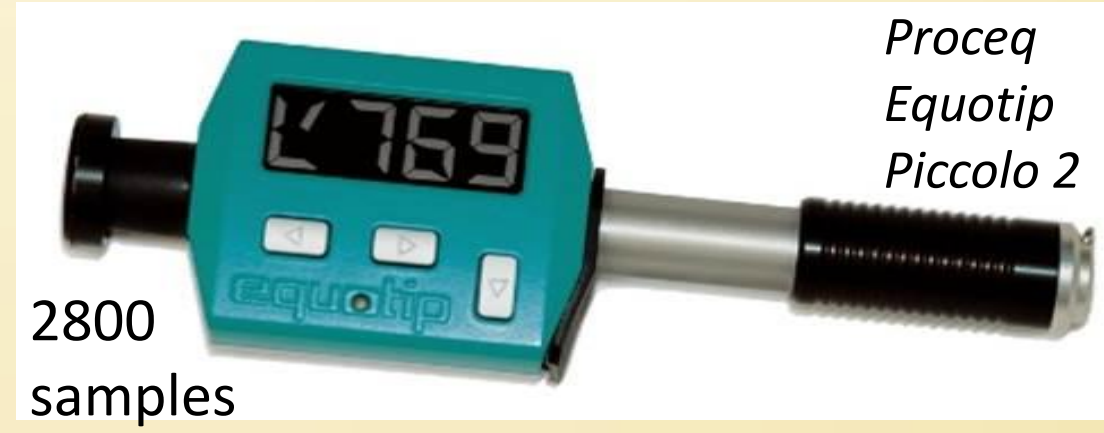

Leeb's Hardness: Indentation hardness measures resistance to material deformation 


\section{Leeb's Hardness Crossplots}
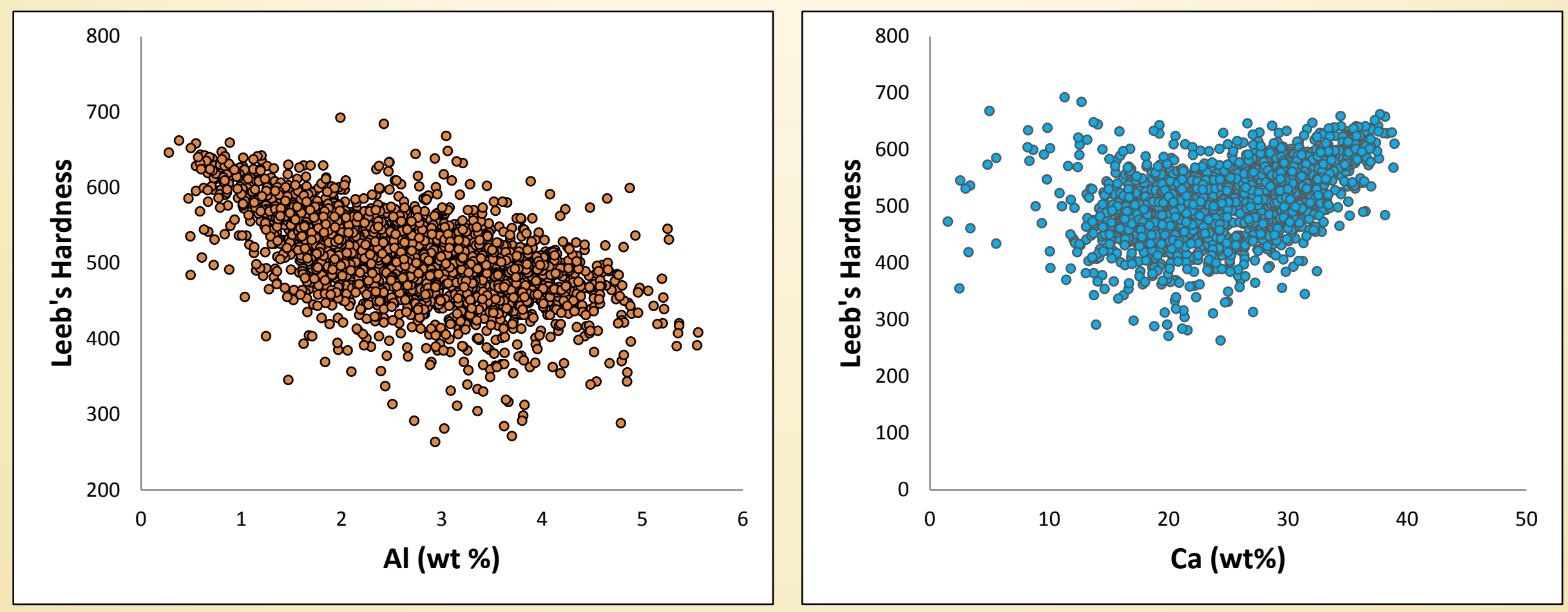

Similar trend for $\mathrm{K}, \mathrm{Th}$, and $\mathrm{Si}$

Soft= Clay

Hard= Carbonate 


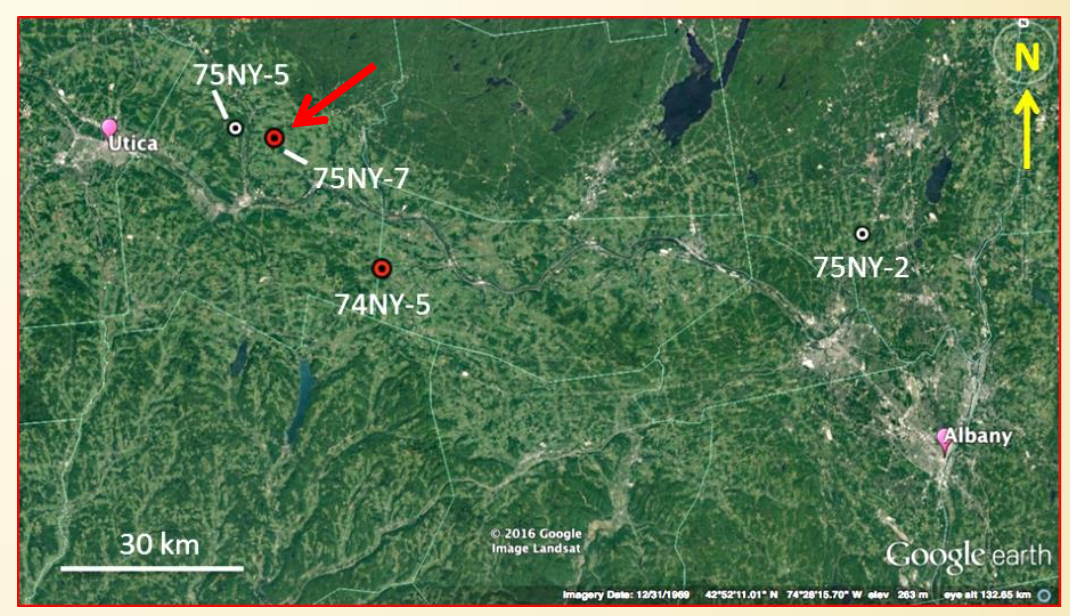

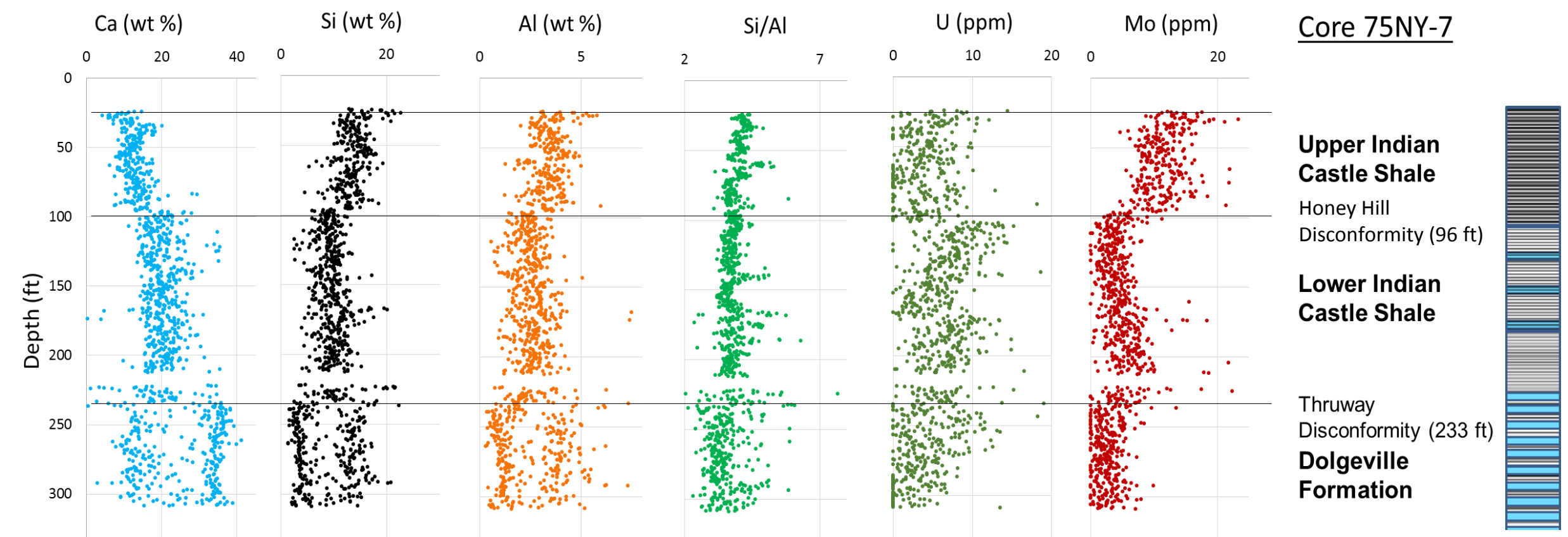




\section{Summary and Future Work}

- Sub-centimeter lithologic description of the entire Utica Group in NY has revealed a variety of unique facies

- Pelagic deposition, turbidity currents, debris flows and possible contour currents contributed to deposition of the Utica Group and Dolgeville Fm

- Chemostratigraphy at 3-inch intervals may help elucidate cryptic, chronostratigraphic horizons such as the lower and upper Indian Castle Shale contact

- Leeb's Hardness values have a negative correlation with $\mathrm{Al}, \mathrm{K}, \mathrm{Th}$, and $\mathrm{Si}$ (clay mineral rich $\rightarrow$ softer), and a positive correlation with $\mathrm{Ca}$ (carbonate beds $\rightarrow$ harder)

Future Work:

- Build stratigraphic columns to compare to XRF and hardness data

- Millimeter-scale XRF analysis with core scanning table

- Correlate litho- and chemostratigraphy to other cores

- Investigate patterns and cyclicity in XRF data (Fourier Analysis) 


\section{Thank You}

Special thanks to:

Sigma Alpha Mu Foundation, for funding part of

this research

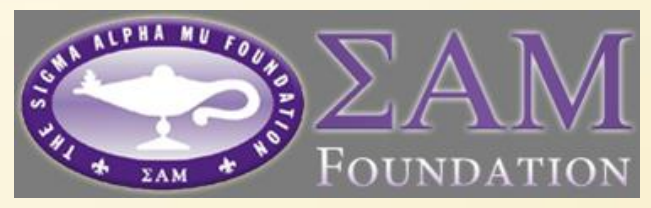

Brian Slater and the NYS Museum, for helping us move cores to Binghamton

Gordon C. Baird, for general discussions and donating hand samples

Proceq, for letting us borrow the Equotip Piccolo 2 for rock hardness testing

맘ㄷ=ㅁㅁ 